\title{
KAJIAN BENTUK KARAKTER RUANG TAMAN TINGKIR SEBAGAI RUANG TERBUKA HIJAU PERKOTAAN KOTA SALATIGA
}

\author{
Febriana Trivita Widayanti ${ }^{1}$ Tjoek Suroso Hadi $^{2}$ \\ Program Studi Perencanaan Wilayah dan Kota Universitas Islam Sultan Agung Semarang ${ }^{1), 2)}$
}

\begin{abstract}
Governments of Salatiga City is being heavily - incessant increase open green space in order to apply the 30\% region used as green open space. Tingkir Park is a form of implementation of the Government program by implementing various concepts in it such as Green Design, Green Open Space, Green Water, and Green Waste. Garden Tingkir can also be used as a playground and sport park equipped with facilities of his supporters so that this becomes the attraction of citizens to make use of the garden. A strong appeal in the region triggered the emergence of a wide range of user activity (public) space by utilizing a variety of spaces in the area Tingkir Park. The goal of the research is going to do that is to find the character space of the area Tingkir park which is a new park strive Government Salatiga city and Office of Copyright works and Spatial Salatiga city to meet the needs open green space in the city who is now a visitor attraction capable of being of local people. The research uses qualitative descriptive method with the deductive approach of Phenomenology .

There are two types of green open space in the Park area, namely Tingkir Park and Tingkir Green Corridor. Open green space Parks Tingkir is active open space and applying the concept of Green Design, Green Open Space, Green Water, and Green Waste. While the green corridors have elongated pattern following the road and serves as a shady, air, and absorption of pollutants. The character of the spaces the Park area was discovered through some Tingkir processes such as find sub themes, themes, and concepts. Sub themes found in the utilization of space in the Park area Tingkir. The theme of the Tingkir Park area found as the lounge, waiting, playing, exercising, and selling. While the concept of identity in the form of categorized into plazas, playgrounds, garden design; the structure of the form of the waiting room, leisure, economy; and meaning in the form of relaxing space. The third component of the space character of area Tingkir Park formulating as the recreation space
\end{abstract}

Keywords: Green Open Space, City Parks, Characters

Pemerintah Kota Salatiga sedang gencar - gencarnya menambah ruang terbuka hijau guna menerapkan 30\% wilayah digunakan sebagai ruang terbuka hijau. Taman Tingkir merupakan bentuk penerapan program pemerintah dengan menerapkan berbagai konsep didalamnya seperti Green Design, Green Open Space, Green Water, dan Green Waste. Taman Tingkir juga dapat digunakan sebagai playground dan sport park yang dilengkapi dengan berbagai fasilitas pendukungnya sehingga hal ini menjadi daya tarik warga untuk memanfaatkan taman tersebut. Daya tarik yang kuat di kawasan ini memicu munculnya berbagai aktivitas pengguna ruang (masyarakat) dengan memanfaatkan berbagai ruang di Kawasan Taman Tingkir.

Tujuan dari penelitian yang akan dilakukan yaitu untuk menemukan karakter ruang kawasan Taman Tingkir yang merupakan taman baru yang upayakan oleh Pemerintah Kota Salatiga dan Dinas Cipta Karya dan Tata Ruang Kota Salatiga untuk memenuhi kebutuhan ruang terbuka hijau di Kota Salatiga yang kini mampu menjadi daya tarik pengunjung masyarakat setempat. Penelitian ini menggunakan metode diskriptif kualitatif dengan pendekatan deduktiffenomenologi. .

Terdapat dua jenis ruang terbuka hijau di Kawasan Taman Tingkir yaitu Taman Tingkir dan Koridor Hijau. Ruang terbuka hijau Taman Tingkir merupakan ruang terbuka aktif dan menerapkan konsep Green Design, Green Open Space, Green Water, dan Green Waste. Sedangkan koridor hijau memiliki pola memanjang mengikuti jalan dan berfungsi sebagai peneduh, penyejuk, dan penyerapan polusi. Karakter ruang kawasan Taman Tingkir ini ditemukan melalui beberapa proses seperti menemukan sub tema, tema, dan konsep. Sub tema ditemukan dalam pemanfaatan ruang di Kawasan Taman Tingkir. Tema yang ditemukan yaitu Kawasan Taman Tingkir sebagai ruang bersantai, menunggu, bermain, berolahraga, dan jual beli. Sedangkan konsep dikategorisasikan menjadi identitas berupa plasa, taman bermain, desain taman; struktur berupa ruang tunggu, rekreasi, ekonomi ; dan makna berupa ruang santai. Ketiga komponen tersebut merumuskan karakter ruang Kawasan Taman Tingkir sebagai ruang rekreasi.

Kata Kunci : Ruang Terbuka Hijau, Taman Kota, Karakter 


\section{PENDAHULUAN}

Pemerintah Kota Salatiga sedang gencar - gencarnya menambah ruang terbuka hijau guna menerapkan 30\% wilayah digunakan sebagai ruang terbuka hijau. Kota Salatiga merupakan salah satu kota yang sedang melaksanakan Program Pengembangan Kota Hijau (P2KH) dengan menetapkan beberapa lokasi untuk dijadikan sebagai ruang terbuka hijau salah satunya yaitu di Kecamatan Tingkir. Penerapan program P2KH di Kecamatan Tingkir yakni dengan memanfaatkan lahan kosong milik pemerintah untuk dijadikan menjadi salah satu Taman Kota di Kota Salatiga dengan sebutan Taman Tingkir. Lokasi taman berada di tengah - tengah permukiman warga, sehingga keberadaan ruang terbuka hijau taman ini dapat menampung aktivitas warga setempat. Seperti yang telah disampaikan oleh salah satu Humas Dinas Ciptaru bahwa pemilihan lokasi untuk ruang terbuka hijau memanfaatkan lahan kosong milik pemerintah (tanah bengkok) yang letaknya strategis dan dekat dengan permukiman warga sehingga dapat menampung aktivitas warga (IR, 2016). Taman Tingkir menerapkan berbagai konsep didalamnya seperti Green Design, Green Open Space, Green Water, dan Green Waste (IR, 2016). Selain konsep - konsep tersebut, Taman Tingkir juga digunakan sebagai playground dan sport park yang dilengkapi dengan berbagai fasilitas pendukungnya sehingga hal ini menjadi daya tarik warga untuk memanfaatkan taman tersebut. Daya tarik yang kuat di kawasan ini memicu munculnya berbagai aktivitas pengguna ruang (masyarakat) dengan memanfaatkan berbagai ruang di Kawasan Taman Tingkir. Pentingnya penelitian mengenai karakter ruang kawasan Taman Tingkir sebagai ruang terbuka hijau perkotaan yaitu untuk mengetahui "Karakter Ruang Yang Terdapat Di Kawasan Taman Tingkir" sehingga karakter tersebut mampu menjadi ciri khas kawasan taman dan mampu menjadi daya tarik masyarakat.

Kawasan taman ini ramai digunakan oleh berbagai kalangan mulai dari anak - anak hingga lansia dan mampu memicu munculnya berbagai aktivitas dan pemanfaatan ruang didalamnya. Taman Tingkir dilengkapi dengan berbagai ruang fasilitas yang dapat dimanfaatkan oleh pengguna ruang seperti pendopo, pedestrian, plasa, taman bermain, taman olahraga dan fasilitas pendukung seperti parkir, toilet, dan pos keamanan. Beragamnya aktivitas pengunjung seperti bermain, berolahraga, duduk - duduk, dan jual beli ditemukan di kawasan Taman Tingkir. Sehingga Taman Tingkir mampu menjadi daya tarik pengunjung dan kawasan Taman Tingkir tampak ramai. Terdapatnya pola hubungan antar pengguna ruang di Kawasan Tingkir dalam beraktivitas, seperti berolahraga, 
bermain, menunggu, jual beli. Sehingga hal ini mampu menciptakan suatu struktur dan makna yang dilakukan oleh pengguna ruang. Tujuan dari penelitian ini adalah untuk menemukan karakter ruang kawasan Taman Tingkir sebagai ruang terbuka hijau Kota Salatiga yang merupakan taman baru yang diupayakan oleh Pemerintah Kota Salatiga dan Dinas Cipta Karya dan Tata Ruang Kota Salatiga untuk memenuhi kebutuhan ruang terbuka hijau di Kota Salatiga yang kini mampu menjadi daya tarik pengunjung masyarakat setempat sehingga memicu beragamnya aktivitas pengguna ruang.

\section{METODOLOGI PENELITIAN}

Metode penelitian yang digunakan dalam penyusunan laporan yang berjudul "Karakter Ruang Kawasan Taman Tingkir Sebagai Ruang Terbuka Hijau Perkotaan Kota Salatiga" adalah metode penelitian deskriptif kualitatif dengan menggunakan pendekatan deduktif fenomenologi.

Menurut Purnomohadi (2001), ruang terbuka hijau merupakan sebentang lahan terbuka tanpa bangunan yang mempunyai ukuran, bentuk, dan batas geografis tertentu dengan status penguasaan apapun. Menurut Edi Purwanto (2007), jenis ruang terbuka hijau binaan adalah ruang atau kawasan yang berbentuk areal memanjang atau mengelompok, dimana penggunaannya lebih bersifat terbuka. Ruang hijau terbuka binaan merupakan upaya untuk menciptakan keseimbangan antara ruang terbangun dan ruang terbuka hijau yang berfungsi sebagai paru-paru kota, peresapan air, pencegahan polusi udara dan perlindungan terhadap flora seperti koridor jalan, koridor sungai, taman, fasilitas olah raga, play ground.

Menurut Rustam Hakim (2004), taman fungsinya digabung dengan fasilitas olah raga, baik berupa lapangan terbuka dengan street furniture, jogging track, biking, dan olah raga lainnya. Taman menjadi sebuah places for play dan sport park. Taman jenis ini disebut sebagai Taman Aktif. Dikatakan sebagai taman aktif apabila di dalamnya di bangun berbagai fasilitas yang menunjang berbagai kegiatan pemakai taman.

Menurut Carr (1992), pola aktivitas pemanfaatan ruang terbuka publik memiliki beberapa faktor yang mempengaruhi yaitu ruang aktivitas, pelaku aktivitas, dan waktu aktivitas.

Karakter ruang suatu kawasan diperkuat dengan tiga komponen sebagai berikut (Lynch, 1960). 
- Identitas, identifikasi dari suatu obyek, yang mampu membedakan dengan obyek lainnya. Identitas dapat menjelaskan bentuk fisik dan menjelaskan posisi atau letak dari obyek fisik tertentu.

- Struktur, gambaran kawasan yang meliputi pengertian ruang atau pola hubungan dari pengamat dengan suatu obyek tertentu serta kaitannya dengan obyek lainnya.

- Makna, sesuatu yang harus dimiliki obyek, sehingga obyek tersebut mempunyai arti bagi pengamat baik secara fungsi maupun emosi, serta dapat menjelaskan adanya perbedaan makna ruang dan pola hubungannya.

\section{HASIL DAN PEMBAHASAN}

\section{Analisis Jenis dan Sifat Ruang Terbuka Hijau Kawasan Taman Tingkir Taman Tingkir}

Taman Tingkir merupakan taman baru di Kota Salatiga yang dibangun pada tahun 2015. Taman Tingkir termasuk pada ruang terbuka hijau binaan dengan menciptakan adanya keseimbangan antara ruang terbangun dan ruang terbuka hijau di Kota Salatiga. Maksud dibangunnya taman ini yaitu guna memenuhi kebutuhan ruang terbuka hijau dan melaksanakan Program Pengembangan Kota Hijau (P2KH). Dimana maksud tersebut merupakan bentuk implementasi dari Perda Kota Salatiga NO.4 tahun 2011 tetang Rencana Tata Ruang Wilayah Kota Salatiga dalam penyediaan RTH kota yang proposional.

Taman Tingkir termasuk pada ruang terbuka hijau binaan dengan menciptakan adanya keseimbangan antara ruang terbangun dan ruang terbuka hijau di Kota Salatiga. Maksud dibangunnya taman ini yaitu guna memenuhi kebutuhan ruang terbuka hijau dan melaksanakan Program Pengembangan Kota Hijau (P2KH). Taman ini termasuk taman kecil dengan luasan $11.000 \mathrm{~m} 2$ yang diletakkan tidak jauh dari kawasan permukiman. Taman Tingkir merupakan ruang terbuka yang sifatnya umum digunakan untuk berbagai kalangan baik dari kalangan anak - anak hingga lansia.

"Fokus utama taman sebagai ruang terbuka aktif dengan fungsi rekreasi karena Kota Salatiga padat penduduk, ruang terbuka terbatas dengan tetap menerapkan konsep lingkungan. Taman ini multifungsi ada taman bermain, taman olahraga, ada pijat refleksi sebetulnya belum merupakan taman tematik space. Biasanya taman identik dengan orang kongkow anak kecil bermain, ada refleksi untuk manula, dan olahraga." (FGS/17$02 / 1 / 2017)$ 
Dari kutipan wawancara diatas dijelaskan bahwa Taman Tingkir merupakan salah satu jenis ruang terbuka aktif di Kota Salatiga. Dikatakan ruang terbuka aktif karena didalamnya mengandung unsur - unsur kegiatan di dalamnya seperti kegiatan olahraga, bermain, dan berjalan - jalan. Berbagai fasilitas penunjang kegiatan ruang terbuka aktif tersedia di taman ini, seperti taman bermain anak, lapangan olahraga, hingga pendopo tempat berkumpul.

Sifat dari Taman Tingkir yakni umum terbuka dimana Taman Tingkir terletak pada suatu lingkungan yang terbuka dan umum dapat dimanfaatkan oleh berbagai kalangan mulai dari anak - anak, lansia, hingga difable. Sifat yang umum tersebut didukung dengan bentuk arsitektur taman yang ramah lingkungan bebas dari anak tangga yang dapat membahayakan dan ramah untuk difable. Selain itu, taman juga dilengkapi dengan berbagai fasilitas untuk anak - anak hingga lansia dimana fasilitas untuk anak - anak seperti taman bermain dan olahraga. Sednagkan fasilitas untuk lansia seperti ruang refleksi kaki yang terdapat pada suatu ruang plasa.

Selain dilengkapi dengan berbagai fasilitas penunjang taman, Taman Tingkir sebagai bentuk implementasi dari Program P2KH juga dilengkapi dengan berbagai atribut Kota Hijau seperti Green Design, Green Open Space, Green Water, dan Green Waste. Berikut merupakan informasi mengenai atribut taman yang didapatkan dari wawancara informan.

"Bentuknya itu seperti “daun” dengan prinsip daun itu hijau. Dan plasa itu sebagai center. Adanya pendopo untuk menampung kepentingan aktifitas masyarakat. Konsep lingkungan diterapkan di taman tersebut karena disana ada pengolahan sampah dan kegiatan rutin daur ulang sampah. Konsep juga tetap eko karena ada kolam retensi untuk fungsi resapan walopun ada limpasan sedikit bagian timur taman. Taman ini sangat ramah untuk kaum manula dan difable karena taman ini tidak terdapat tangga dan lahan termasuk datar." (FLF/10-02/1/2017) 


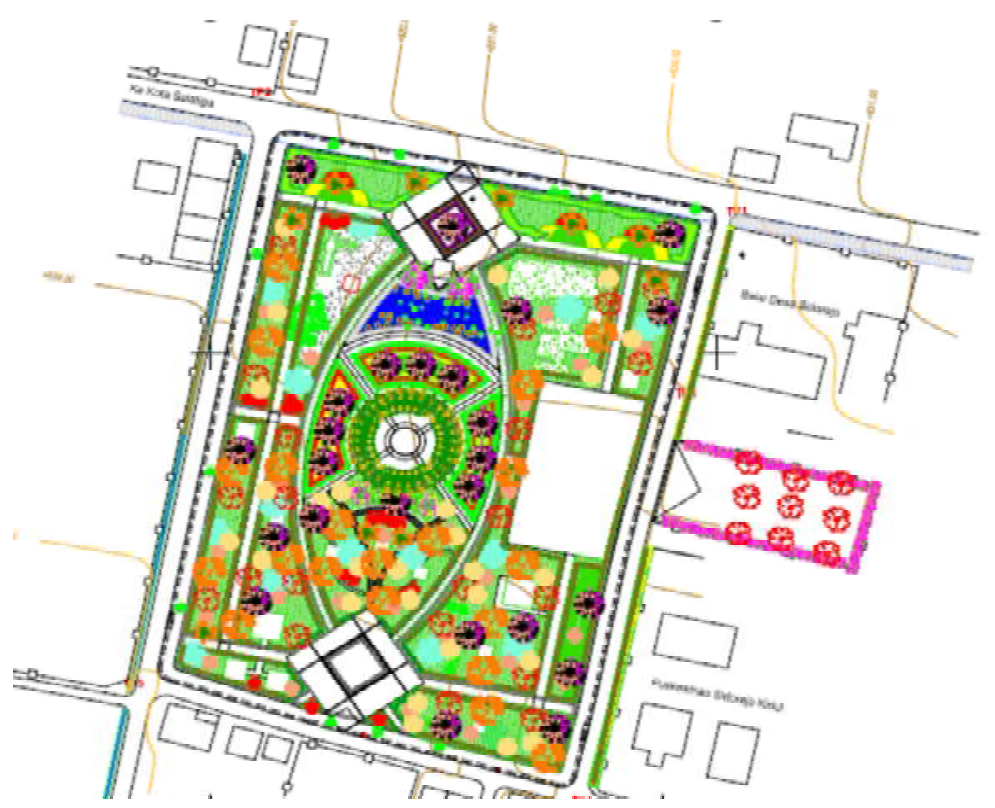

Gambar 1. Siteplan Taman Tingkir

Green Design yang diterapkan pada Taman Tingkir berupa bentuk arstektur yang tergambar dalam siteplan dengan bentuk bagian tengah lengkungan seperti "daun" menggambarkan bahwa daun hijau sehingga untuk menerapkan konsep kota hijau menggunakan ilusi sebuah daun. Untuk mendukung konsep tersebut maka di tambahkan vegetasi yang sebagian besar berupa daun - daunan perdu. Fokus taman berada di bagian tengah berupa plasa dengan filosofi bahwa tempat berkumpul center of interest berada pada fokus tengah. Pada lokasi tersebut, diharapkan pengunjung dapat menikmat keindahan taman secara keseluruhan.

Green Open Space yang dituju berupa kuantitas proporsi kebutuhan ruang terbuka hijau perkotaan sebesar 30\% dari luas wilayah. Keberadaan Taman Tingkir ini salah satunya dimaksudkan untuk memenuhi kebutuhan ruang terbuka hijau di Kota Salatiga.

Green Water, dimaksudkan untuk mengefisiensi pemanfaatan sumber daya air untuk keberlangsungan hidup dengan memaksimalkan penyerapan air dan mengurangi limpasan air. Konsep ini diterapkan di Taman Tingkir pada bagian kolam retensi yang berada di bagian depan taman dengan tujuan untuk mengurangi limpasan air hujan.

Green Waste, berupa upaya pengolahan sampah dengan menerapkan kosep 3R : Reduce (mengurangi sampah), Reuse (memberikan nilai tambah bagi sampah hasil daur ulang), dan Recycle(mendaur ulang sampah). Salah satu atribut taman yang memanfaatkan daur ulang sampah yaitu pada bangku taman yang menggunakan bekas drum dan bekas 
botol - botol. Selain itu, di Taman ini juga diadakan kegiatan KISS (Kreasi dan Inovasi Sampah Salatiga) yang diadakan secara rutin pada hari Selasa setiap minggu ke 1 dan ke 3 yang diadakan oleh Dinas Ciptakaru Kota Salatiga.
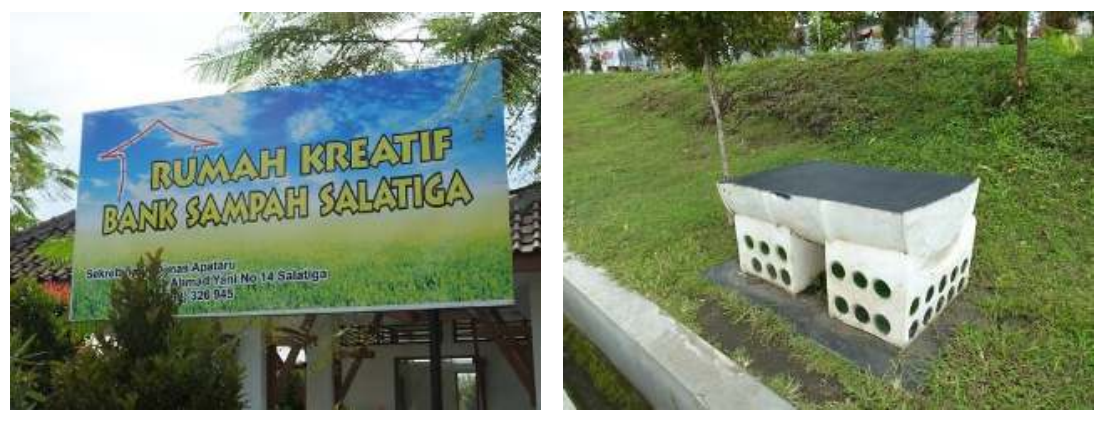

Gambar 2 Green Waste di Taman Tingkir

Sumber : Dokumentasi Penyusun, 2017

\section{Analisis Pemanfaatan Ruang dan Aktivitas Kawasan Taman Tingkir \\ Pemanfaatan Ruang}

Pemanfaatan ruang yang ditemukan di Kawasan Taman Tingkir adalah sebagai berikut

Tabel 1. Aktivitas Pemanfaatan Ruang di Kawasan Taman Tingkir

\begin{tabular}{|c|c|c|}
\hline Ruang & Waktu & Pemanfaatan Ruang \\
\hline \multirow[t]{2}{*}{ Plasa } & Hari Kerja & $\begin{array}{l}\text { - Duduk - duduk } \\
\text { - Mengobrol } \\
\text { - Menunggu anak bermain } \\
\text { - Berfoto - foto } \\
\text { - Refleksi kaki }\end{array}$ \\
\hline & $\begin{array}{l}\text { Hari Libur/ } \\
\text { Sabtu-Minggu }\end{array}$ & $\begin{array}{l}\text { - Refleksi kaki } \\
\text { - Bermain mobil - mobilan mini anak } \\
\text { - Lari - lari/jogging } \\
\text { - Mengobrol } \\
\text { - Bermain scooter } \\
\text { - Atraksi hewan (ular, burung, kucing) } \\
\text { - Berfoto - foto } \\
\text { - Duduk - duduk }\end{array}$ \\
\hline \multirow[t]{2}{*}{ Pedestrian/trotoar } & Hari Kerja & $\begin{array}{l}\text { - Berjualan makanan } \\
\text { - Menunggu orang } \\
\text { - Lari pagi } \\
\text { - Tempat sewa mainan anak (mobil-mobilan, } \\
\text { scooter) } \\
\text { - Jalan- jalan }\end{array}$ \\
\hline & $\begin{array}{l}\text { Hari Libur/ } \\
\text { Sabtu-Minggu }\end{array}$ & $\begin{array}{l}\text { - Jual beli makanan } \\
\text { - Menyewakan mainan anak } \\
\text { - Lari - lari/jogging } \\
\text { - Jalan - jalan } \\
\text { - Bermain sepatu roda } \\
\text { - Bermain scooter, mobilan }\end{array}$ \\
\hline
\end{tabular}




\begin{tabular}{|c|c|c|}
\hline Ruang & Waktu & Pemanfaatan Ruang \\
\hline & & $\begin{array}{l}\text { - Duduk - duduk } \\
\text { - Mengobrol } \\
\text { - Menunggu orang }\end{array}$ \\
\hline \multirow[t]{2}{*}{ Koridor Hijau } & Hari Kerja & $\begin{array}{l}\text { - Duduk - duduk } \\
\text { - Menunggu orang } \\
\text { - Berjualan mainan } \\
\text { - Berjualan makanan } \\
\end{array}$ \\
\hline & $\begin{array}{l}\text { Hari Libur/ Sabtu - } \\
\text { Minggu }\end{array}$ & $\begin{array}{l}\text { - Menunggu orang } \\
\text { - Nogkrong dengan teman } \\
\text { - Berjualan makanan } \\
\text { - Duduk - duduk } \\
\text { - Jual mainan }\end{array}$ \\
\hline \multirow[t]{2}{*}{ Taman Bermain } & Hari Kerja & $\begin{array}{l}\text { - Bermain ayunan, jungkat jungkit } \\
\text { - Bermain anak sekolah jam istirahat } \\
\text { - Berfoto - foto } \\
\text { - Menunggu cucu }\end{array}$ \\
\hline & $\begin{array}{l}\text { Hari Libur/ } \\
\text { Sabtu-Minggu }\end{array}$ & $\begin{array}{l}\text { - Bermain permainan anak } \\
\text { - Foto - foto }\end{array}$ \\
\hline \multirow[t]{2}{*}{$\begin{array}{l}\text { Taman Sehat/Lapangan } \\
\text { Olahraga }\end{array}$} & Hari Kerja & $\begin{array}{l}\text { - Jogging pagi, sore hari } \\
\text { - Berfoto - foto } \\
\text { - Sepak bola dengan teman } \\
\end{array}$ \\
\hline & $\begin{array}{l}\text { Hari Libur/ } \\
\text { Sabtu-Minggu }\end{array}$ & $\begin{array}{l}\text { - Jogging } \\
\text { - Sepak bola bersama teman } \\
\text { - Bermain Voli bersama } \\
\text { - Bermain mobile remote } \\
\text { - Bermain scooter } \\
\text { - Berfoto - foto } \\
\end{array}$ \\
\hline \multirow[t]{2}{*}{ Pendopo } & Hari Kerja & $\begin{array}{l}\text { - Menunggu teman } \\
\text { - Duduk - duduk } \\
\text { - Menunggu anak bermain } \\
\text { - Tempat bercengrama dengan teman } \\
\text { - Menikmati makan } \\
\end{array}$ \\
\hline & $\begin{array}{l}\text { Hari Libur/ } \\
\text { Sabtu-Minggu }\end{array}$ & $\begin{array}{l}\text { - Menunggu anak bermain } \\
\text { - Tempat istirahat } \\
\text { - Tempat bersantai } \\
\text { - Mengobrol } \\
\text { - Duduk - duduk } \\
\text { - Tempat menikmati jajanan } \\
\text { - Menunggu teman }\end{array}$ \\
\hline
\end{tabular}

\section{Aktivitas Ruang Kawasan Taman Tingkir}

Analisis aktivitas ruang Kawasan Taman Tingkir membahas mengenai berbagai aktivitas yang telah ditemukan pada subab sebelumnya mengenai pemanfaatan ruang Kawasan Taman Tingkir yang ditemukan melalui pengamatan langsung. Namun dalam pembahasan analisis ini melibatkan hasil wawancara dari pengguna ruang untuk 
memperkuat munculnya tema - tema yang telah ditemukan. Berikut merupakan pembahasan tema - tema yang telah dihasilkan dari proses pengelompokan sub - sub tema.

Perumusan temuan tema Kawasan Taman Tingkir sebagai ruang bersantai didapatkan dari pengamatan langsung dan informasi dari pengguna ruang melalui teknik wawancara. Perumusan tema ini berdasarkan dari sub - sub tema yang telah ditemukan. Tema Taman Tingkir sebagai ruang bersantai didapatkan dari hasil pengelompokan sub tema pengguna ruang yang melakukan aktivitas nongkrong, duduk - duduk, menikmati makanan, jajan, berfoto dan berbincang - bincang. Perumusan tema Taman Tingkir sebagai ruang bersantai dapat dilihat pada diagram abstraksi berikut ini.

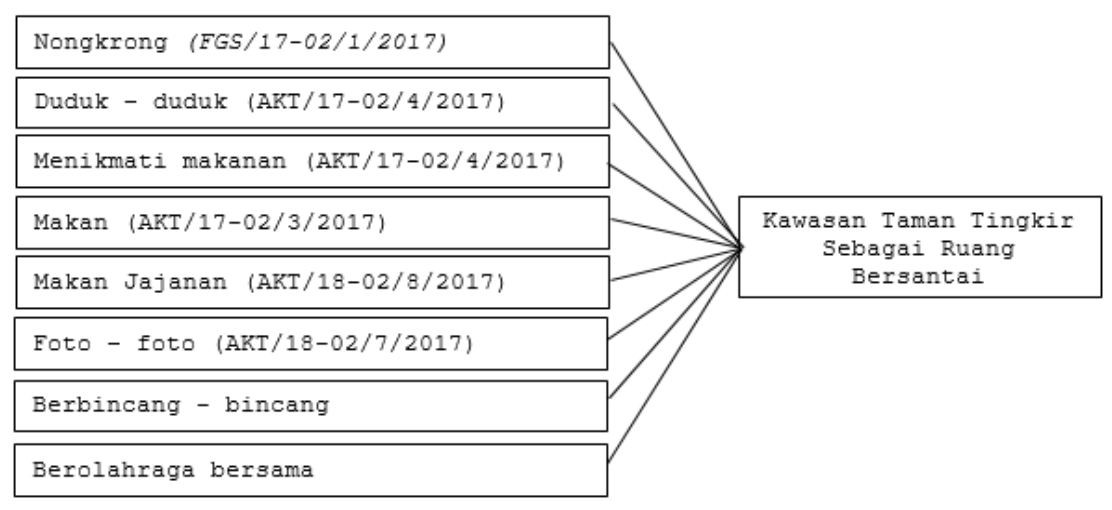

Gambar 3 Diagram Abtraksi Kawasan Taman Tingkir Sebagai Ruang Bersantai Sumber : Hasil Analisis, 2017

Aktivitas duduk - duduk dan berbincang - bincang ini banyak ditemui di plasa, pendopo dan pedestrian. Adapun pengguna ruang yang melakukan aktivitas bersantai cukup beragam mulai dari anak - anak, orang dewasa hingga lansia. Aktivitas bersantai di Taman Tingkir ini tidak hanya dilakukan oleh masyarakat sekitar taman, namun juga dimanfaatkan oleh masyarakat luar daerah.

Perumusan tema Kawasan Taman Tingkir sebagai ruang menunggu diperoleh dari sub tema nunggu temen, nunggu anak, dan nunggu cucu. Sub tema tersebut diperoleh dari hasil pengamatan langsung dan wawancara kepada pengguna ruang. Berikut gambaran diagram abstraksi tema Taman Tingkir sebagai ruang menunggu. 


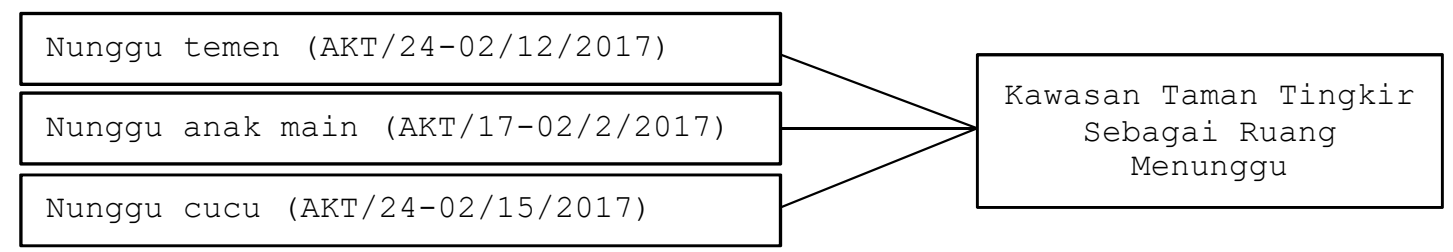

Gambar 4 Diagram Abtraksi Tema Kawasan Taman Tingkir Sebagai Ruang Menunggu Sumber : Hasil Analisis, 2017

Aktivitas menunggu yang ditemukan di Taman Tingkir yaitu aktivitas menunggu teman dan menunggu anggota keluarganya yang sedang bermain. Beberapa lokasi ruang yang dimanfaatkan untuk menunggu teman maupun anggota keluarganya yaitu pendopo, pedestrian, dan bangku - bangku di plasa. Sebagian besar pengguna ruang yang menunggu temannya yaitu anak remaja, sedangkan pengguna ruang yang menunggu anggota keluarganya terutama menunggu anaknya bermain yaitu orang tua. Berikut beberapa alasan pengguna ruang yang menggunakan Taman Tingkir sebagai tempat untuk menunggu teman.

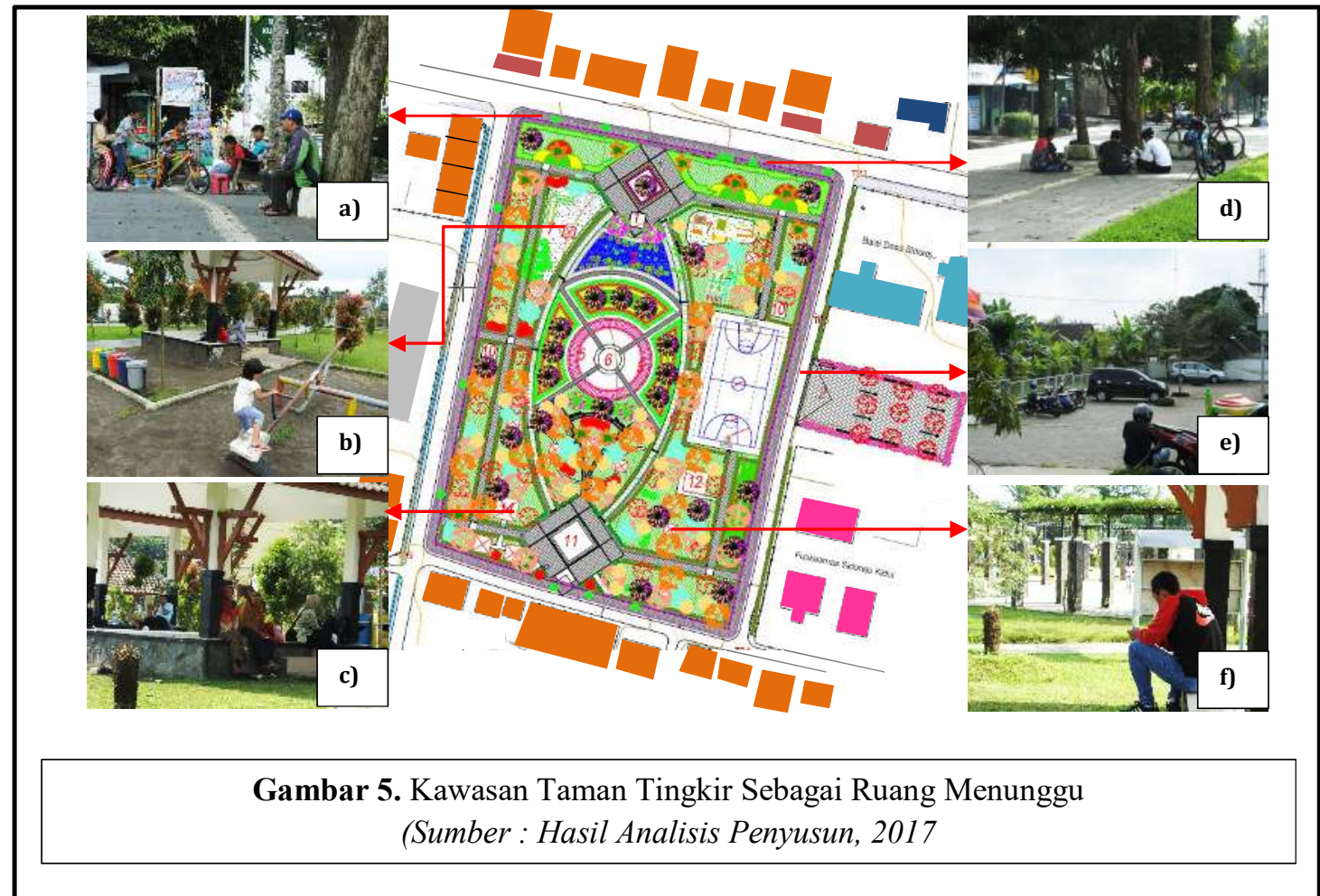

Perumusan tema empiris Kawasan Taman Tingkir sebagai ruang bermain diperoleh dari sub tema aktivitas yang dilakukan oleh pengguna ruang seperti bermain scooter, mobil - mobilan, ayunan, bermain sepatu roda, bermain sepeda, dan berlarian. Sub tema 
tersebut diperoleh dari pengamatan langsung peneliti dan informasi dari hasil wawancara terhadap pengguna ruang. Tema ini membahas mengenai aktivitas bermain yang dilakukan oleh pengguna ruang beserta dengan ruang - ruang yang digunakan. Berikut gambaran diagram abstraksi tema Kawasan Taman Tingkir sebagai ruang bermain.

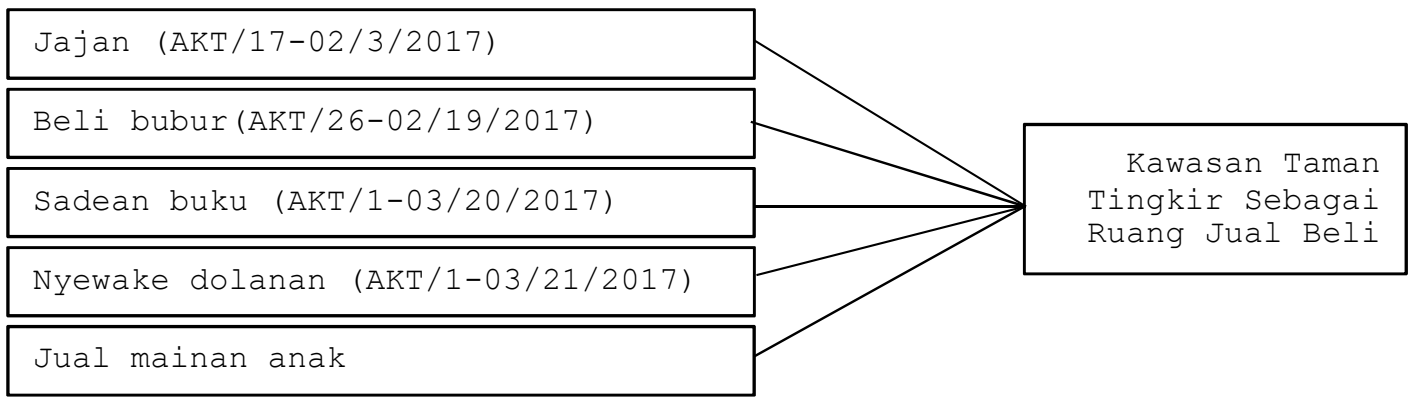

Gambar 6. Diagram Abtraksi Kawasan Taman Tingkir Sebagai Ruang jual Beli

Aktivitas jual beli merupakan aktivitas yang sering ditemui di berbagai ruang publik. Aktivitas ini juga di temui di sisi - sisi Taman dengan memanfaatkan sebagian ruang pedestrian. Pengguna ruang yang melakukan aktivitas berjualan di pedestrian tersebut sebagian besar berasal dari masyarakat setempat. Adapun barang yang dijual ada mainan anak, jajanan, dan buku - buku. Beberapa juga ditemui aktivitas penyewaaan mainan anak seperti mobil - mobilan, scooter, dan sepatu roda. Aktivitas jual beli ini menjadi aktivitas pendukung pengguna ruang pada saat menikmati Taman Tingkir. Aktivitas ini dinilai menjadi pendukung pengguna ruang saat berkunjung ke taman. Apabila ingin menikmati jajanan maka pengguna ruang dapat menikmatinya langsung didekat taman. Berbagai jenis barang/makanan yang dijual tersebut sebagan besar merupakan jajanan makanan kecil seperti batagor, siomay, lutisan buah, sosis dan bakso bakar. Selain kegiatan jual makanan atau mainan anak - anak, disana juga tersedia penyewaan permainan anak. Walaupun tidak tersedianya ruang untuk berjualan, pedagang - pedagang tersebut tetap memanfaatkan sebagian pedestrian dan bahu jalan untuk membuka lapaknya. Aktivitas jual beli ini tidak hanya terjadi di sisi - sisi taman, tetapi beberapa rumah warga yang berada di dekat taman juga dialih fungsikan sebagai lahan mencari keuntungan dengan berjualan jajanan. Maraknya aktivitas jual beli di sekitar Taman Tingkir menjadi tujuan tersendiri bagi pengguna ruang untuk sengaja datang menikmati kuliner jajanan yang telah tersedia. Berikut persebaran aktivitas jual beli yang terdapat di Taman Tingkir. 


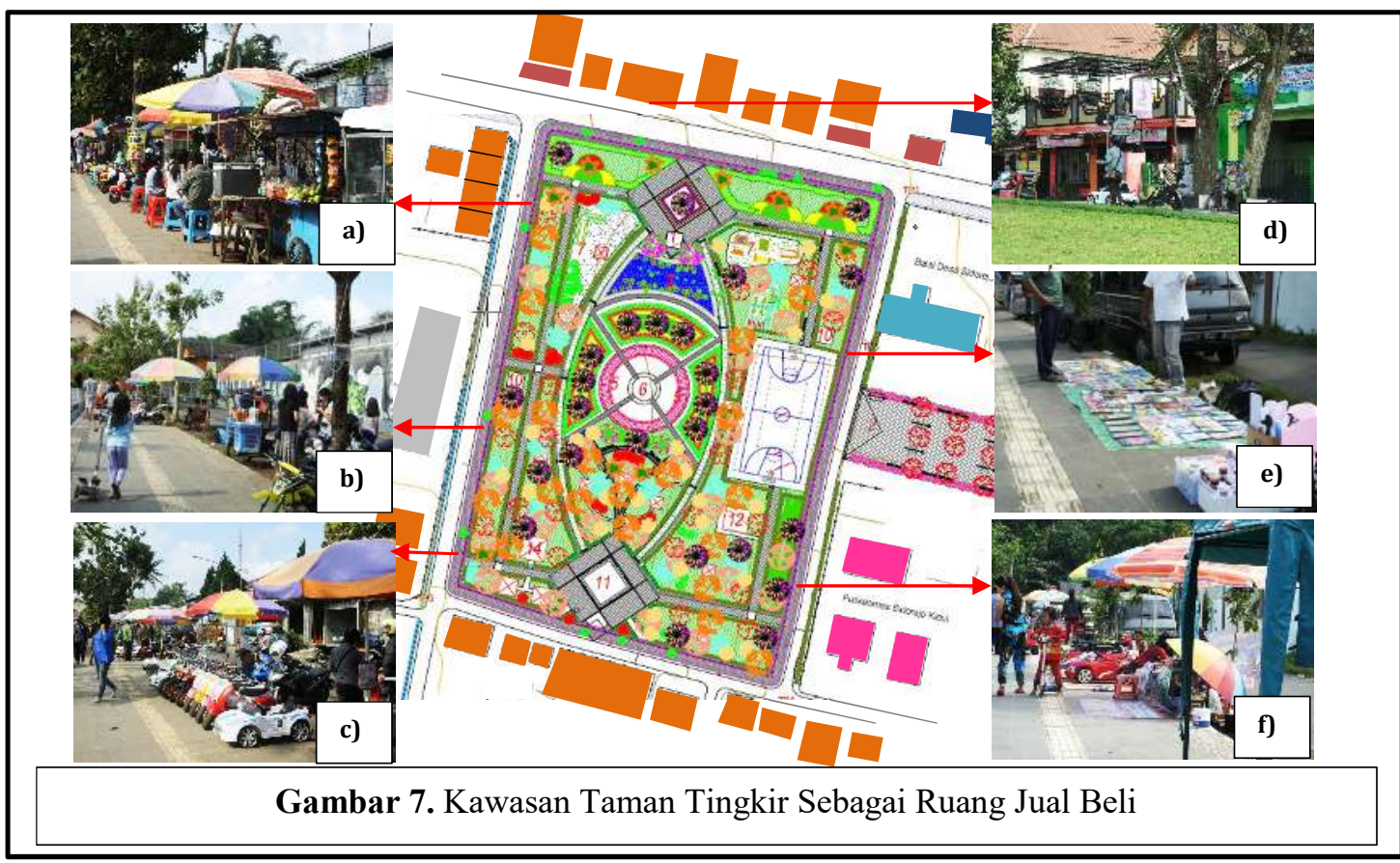

\section{Analisis Karakter Ruang Kawasan Taman Tingkir \\ Identitas}

Plasa, sebagai salah satu identitas Kawasan Taman Tingkir karena plasa merupakan center atau pusat Taman Tingkir dengan bentuk yang unik. Taman bermain, sebagai identitas Kawasan Taman Tingkir karena dilengkapi dengan beragam permainan anak. Desain taman, yang unik menjadi identitas Kawasan Taman Tingkir dimana terdapat berbagai fasilitas yang didesain secara unik seperti bangku. Desain plasa yang merupakan ruang utama ini memperhatikan estetika dimana plasa dilengkapi dengan pergola dan ditumbuhi dengan tanaman rambat.

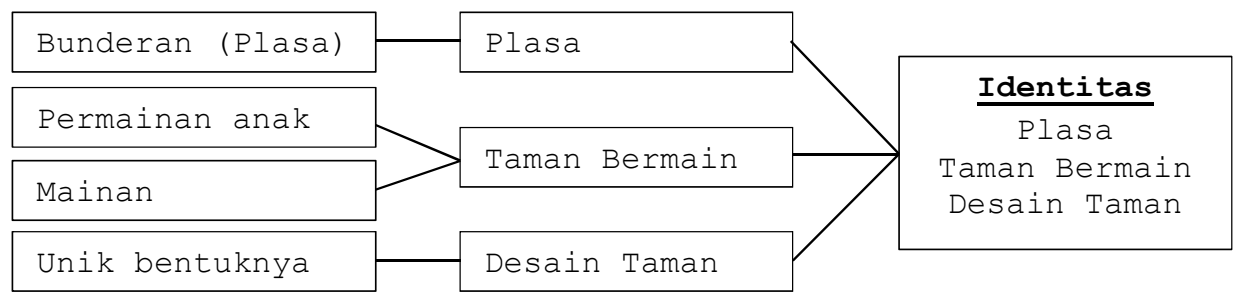

Gambar 8 Diagram Abtraksi Identitas Kawasan Taman Tingkir

Sumber : Hasil Analisis, 2017

\section{Struktur}

Ruang rekreasi, setiap ruang rekreasi terdapat suatu hubungan interaksi antar pengguna ruang. Ruang ekonomi, memiliki pola hubungan antar pembeli dengan penjual, pembeli dengan pembeli, serta penjual dengan penjual. 


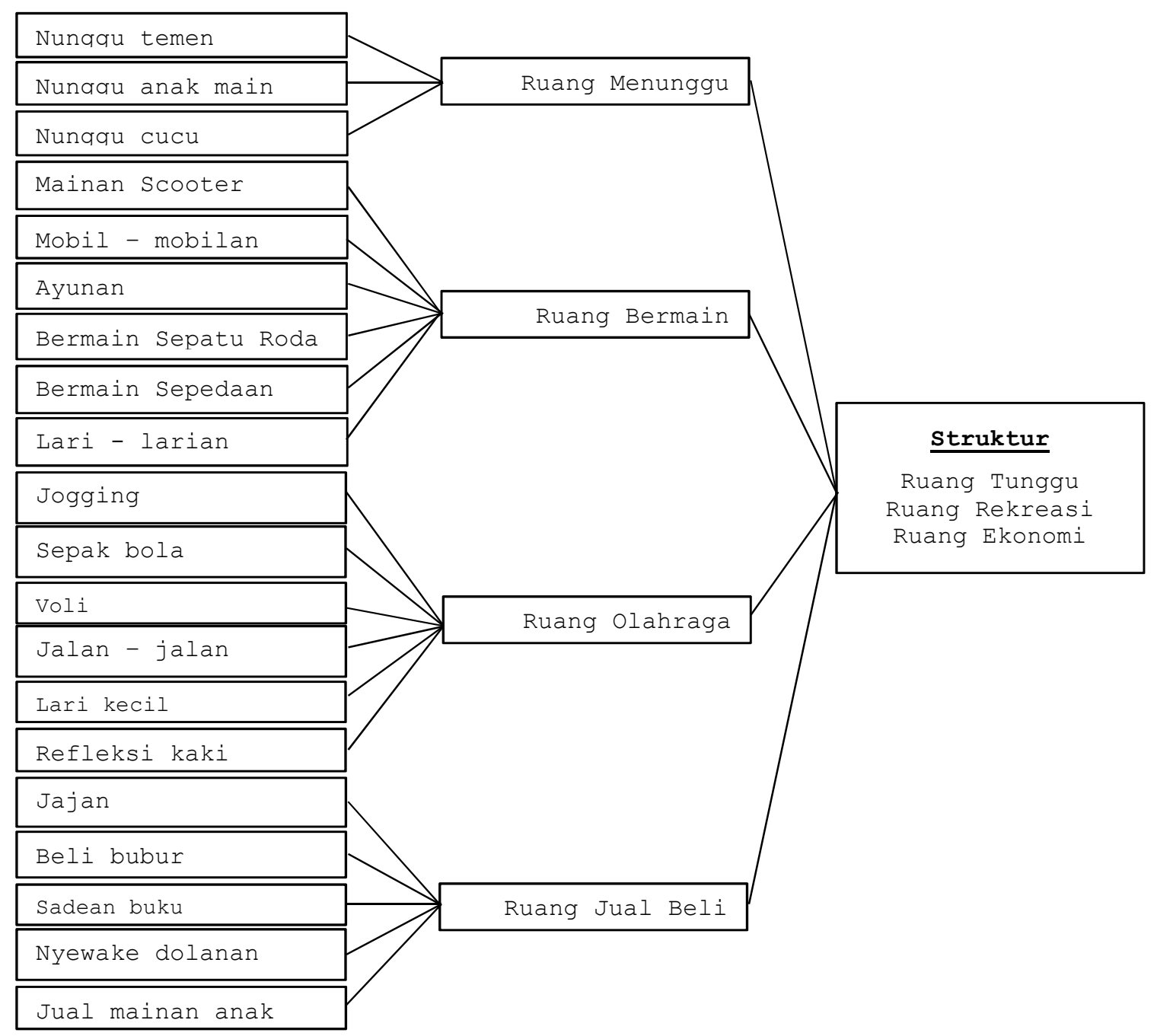

Gambar 9 Diagram Abtraksi Struktur Kawasan Taman Tingkir

Sumber : Hasil Analisis, 2017

Berdasarkan diagram abastraksi kategorisasi diatas, ruang tunggu, rekreeasi dan ekonomi termasuk pada struktur karena ketiga memiliki pola hubungan antar pengguna ruang adanya interaksi satu sama lain. Pada ruang tunggu, pengguna ruang memiliki maksud untuk menunggu seseorang dimana nantinya akan terjadi interaksi dan terdapat hubungan antara objek (pengguna ruang). Menunggu teman, pengguna ruang akan melakukan interaksi dengan temannya apabila sudah bertemu. Menunggu anak yang sedang bermain, pengguna ruang menunggu anaknya yang sedang bermain apabila anak tersebut telah usai bermain maka pengguna ruang dan anak tersebut akan melakukan suatu hubungan interaksi, begitu pula yang terjadi pada menunggu cucu. Proses menunggu ini merupakan suatu aktivitas yang akan menghasilkan suatu hubungan interaksi antar objek (penggun ruang). 


\section{Makna}

Makna menurut Lynch (1960) merupakan sesuatu yang harus dimiliki obyek, sehingga obyek tersebut mempunyai arti bagi pengamat baik secara fungsi maupun emosi, serta dapat menjelaskan adanya perbedaan makna ruang dan pola hubungannya. Objek dalam penelitian ini yaitu aktivitas pengguna ruang yang memiliki arti secara fungsi dan emosional. Berikut merupakan diagram abstraksi makna ruang bersantai di Kawasan Taman Tingkir.

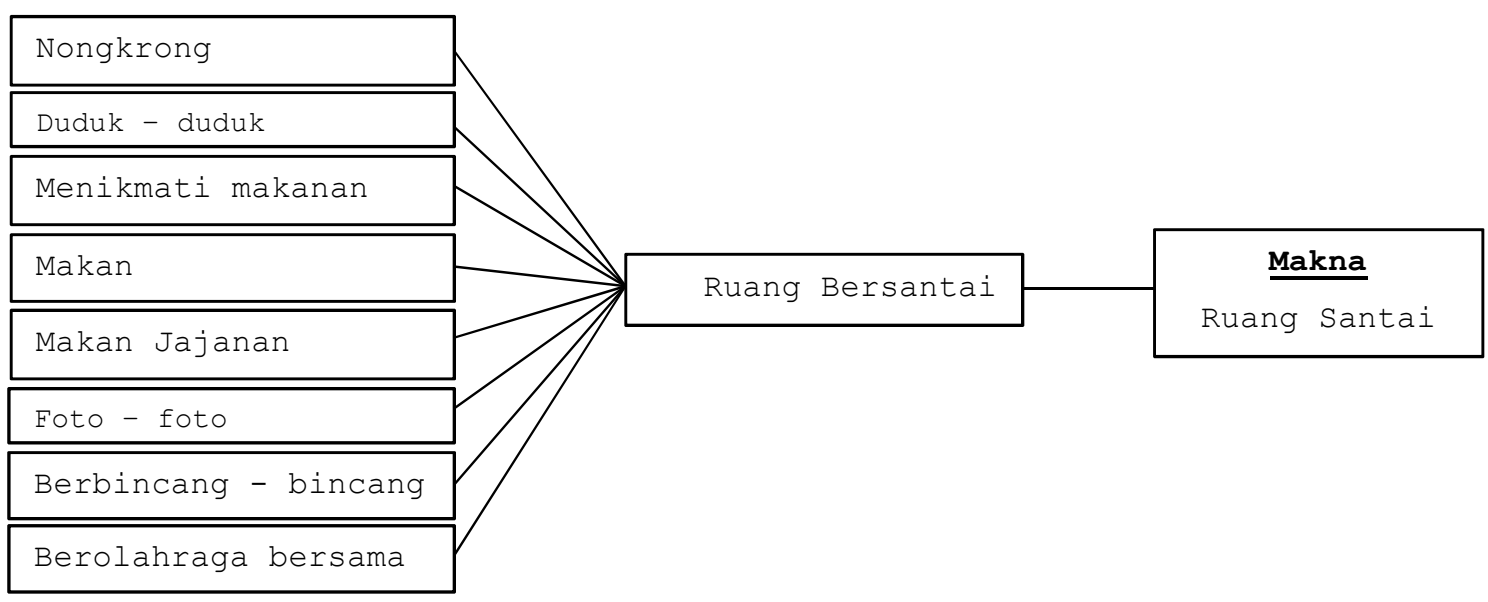

Gambar 10 Diagram Abtraksi Makna Kawasan Taman Tingkir

Sumber : Hasil Analisis, 2017

Makna yang terdapat pada Kawasan Tingkir yaitu sebagai ruang bersantai dimana didalamnya terdapat beberapa aktivitas bersantai seperti nongkrong, duduk - duduk, menikmati makanan, foto - foto, berbincang - bincang dan berolahraga bersama. Aktivitas - aktivitas tersebut dapat menciptakan keadaan kembali seimbang dan pikiran jernih tanpa adanya suatu ketegangan didalamnya. Berolahraga sering sekali dianggap sebagai aktivitas yang menegangkan, namun olahraga di taman ini hanya digunakan sebagai hiburan karna tidak adanya suatu kompetisi didalamnya. Ruang santai, dapat menciptakan keadaan kembali seimbang dan pikiran jernih tanpa adanya suatu ketegangan didalamnya.

\section{Karakter Ruang Kawasan Taman Tingkir Sebagai Ruang Rekreasi}

Karakter ruang Kawasan Taman Tingkir yaitu sebagai ruang rekreasi, dimana menurut Badudu, Zain (1996) rekreasi merupakan penyegaran kembali badan (fisik) dan pikiran; sesuatu yang menggembirakan dan menyegarkan. 


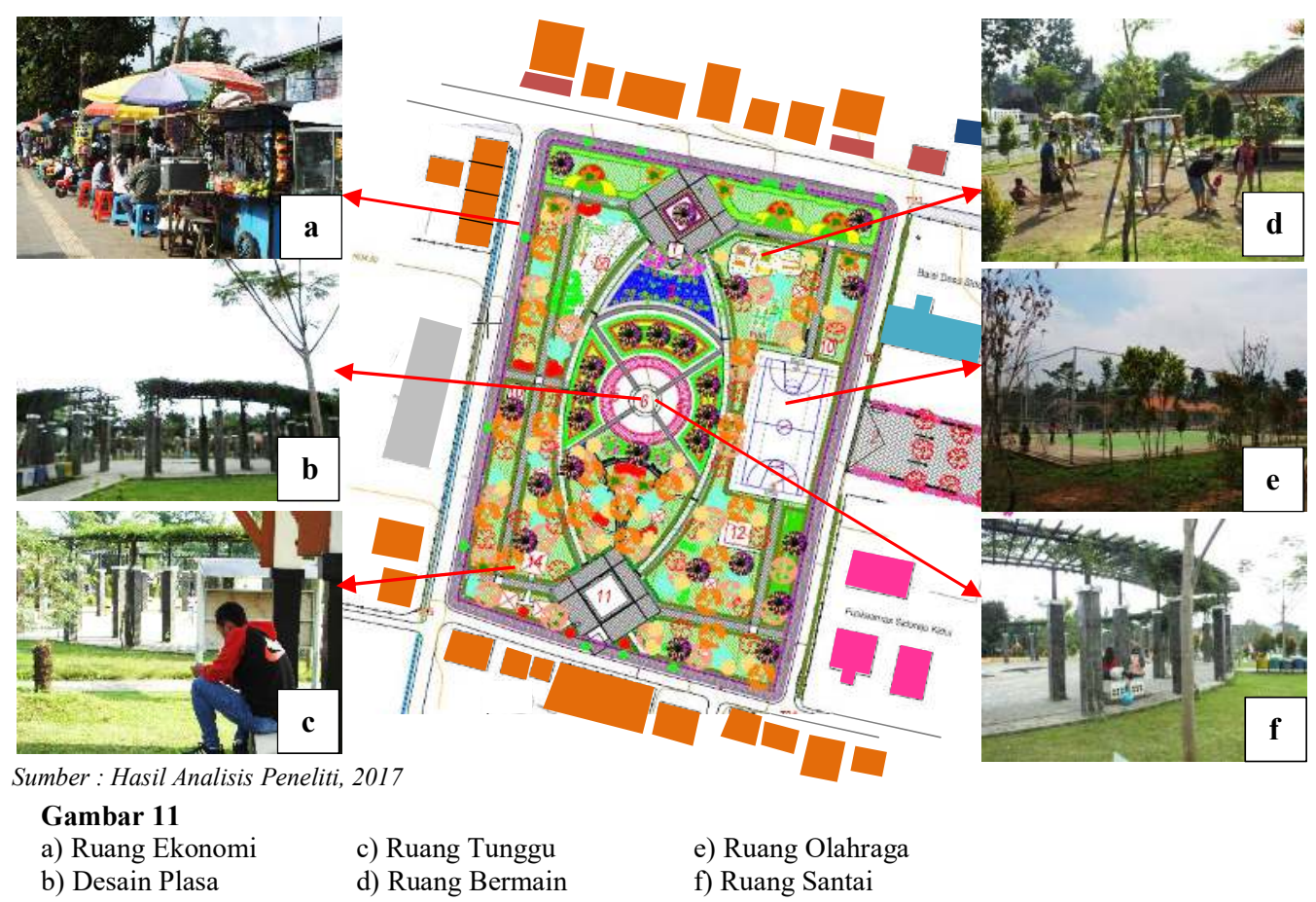

\section{Rekreasi Penyegaran Pikiran}

Plasa, merupakan ruang penyegaran pikiran karena pada ruang ini dilegkapi dengan fasilitas bangku untuk duduk menikmati pemandangan keindahan taman dan kesejukan taman.

Taman bermain, sebagai ruang penyegaran pikiran dilengkapi dengan berbagai permainan anak seperti ayunan, jungkat - jungkit dan komedi putar. Pengguna ruang terlihat bergembira menikmati berbagai fasilitas yang tersedia dan dapat menyegarkan pikirannya.

Desain taman, yang unik menjadi perhatian pengguna ruang. Adapun desain taman yang dinilai memiliki keunikan yaitu bangku taman yang dibuat dari barang bekas dimana hal ini dinilai cukup kreatif dalam mengolah barang bekas. Adanya produk dari barang bekas dan didukung dengan adanya program umum KISS (Kreasi Inovasi Sampah Salatiga) yang diharapkan dapat meningkatkan kreatifitas masyarakat dalam mengolah sampah dan menambah produk - produk kreatif di Taman Tingkir. Kegiatan kreasi ini dapat menjadi suatu selingan penyegaran pikiran bagi pengguna ruang yang mengikutinya. Berbagai tanaman indah yang tersebar di Taman Tingkir memberikan kesan indah dan sejuk, sehingga pengguna ruang yang berkunjung dapat menikmati kesejukan taman. 
Ruang tunggu, pengguna ruang menunggu dengan duduk menikmati pemandangan dan kesejukan taman sehingga pengguna ruang tersebut dapat melakukan penyegaran pikiran dengan menunggu seseorang.

Ruang rekreasi, rekreasi yang termasuk pada penyegaran pikiran yaitu bermain. Rekreasi bermain merupakan hal yang sangat menggembirakan bagi pengguna ruang.

Ruang ekonomi, pengguna ruang yang sedang berkunjung berekreasi di taman dapat menikmati berbagai makanan, minuman, mainan yang dijual di ruang ekonomi ini. Pada saat menikmati makanan, minuman hingga permainan yang dijual, pengguna ruang menikmatinya dengan duduk bersantai sehingga hal itu mampu menjadikan sebagai ruang penyegaran pikiran.

Ruang bersantai, di Kawasan Taman Tingkir dapat dilakukan oleh pengguna ruang untuk menikmati kesejukan, kenyamanan, dan keindahan taman dengan duduk duduk, menikmati makanan, berfoto - foto

\section{Rekreasi Penyegaran Fisik}

Ruang rekreasi, berupa ruang olahraga yang mampu menjadi rekreasi penyegaran fisik dimana pengguna ruang melakukan berbagai kegiatan olahraga seperti bermain voli, sepak bola dll.

Ruang bersantai, menjadi salah satu rekreasi penyegaran fisik karena dalam bersantai ditemui kegiatan berolahraga bersama teman dimana kegiatan itu cenderung merupakan kegiatan olahraga yang santai tidak adanya kompetisi dalam olahraga tersebut.

Plasa, sebagai ruang utama di Kawasan Taman Tingkir dilengkapi dengan ruang refleksi kaki yang biasa digunakan oleh pengunjung untuk refleksi.

\section{KESIMPULAN DAN SARAN}

\section{A. Kesimpulan}

Taman Tingkir termasuk pada ruang terbuka hijau binaan dengan menciptakan adanya keseimbangan antara ruang terbangun dan ruang terbuka hijau di Kota Salatiga. Maksud dibangunnya taman ini yaitu guna memenuhi kebutuhan ruang terbuka hijau dan melaksanakan Program Pengembangan Kota Hijau (P2KH). Dimana maksud tersebut merupakan bentuk implementasi dari Perda Kota Salatiga NO.4 tahun 2011 tetang Rencana Tata Ruang Wilayah Kota Salatiga dalam penyediaan RTH kota yang proposional. Sifat dari Taman Tingkir yakni umum terbuka dimana Taman Tingkir terletak 
pada suatu lingkungan yang terbuka dan umum dapat dimanfaatkan oleh berbagai kalangan mulai dari anak - anak, lansia, hingga difable.

Pemanfaatan ruang yang ditemui di Kawasan Taman Tingkir dilihat dari beberapa ruang utama di Kawasan Taman Tingkir seperti plasa sebagai ruang duduk - duduk, ngobrol, bermain dan berfoto - foto; pedestrian sebagai ruang berjualan, menunggu, duduk - duduk, dan ngobrol; koridor hijau sebagai ruang duduk - duduk, menunggu, berjualan; taman bermain sebagai ruang bermain, menunggu, berfoto - foto; taman olahraga sebagai ruang olahraga, ber foto - foto; pendopo sebagai ruang menunggu, duduk - duduk, makan. Pemanfaatan ruang tersebut merupakan sub tema untuk merumuskan suatu tema aktivitas yang terdapat di Kawasan Taman Tingkir. Adapun bentuk aktivitas yang terdapat di kawasan ini yaitu Kawasan Taman Tingkir sebagai ruang bersantai, ruang menunggu, ruang bermain, ruang berolahraga, dan ruang jual beli.

Karakter ruang Kawasan Taman Tingkir dihasilkan dari komponen identitas, struktur dan makna. Dimana komponen identitas yang dibentuk berupa plasa, taman bermain dan desain taman. Komponen strukur berupa ruang menunggu, ruang rekreasi dan ruang ekonomi. Sedangkan makna berupa ruang santai. Dari ketiga komponen tersebut dapat dirumuskan bahwa karakter ruang Kawasan Taman Tingkir yaitu sebagai ruang rekreasi.

\section{B. Saran}

Tersedianya ruang terbuka hijau aktif Taman Tingkir membawa dampak positif untuk masyarakat Kota Salatiga, karena ini merupakan wajah baru di Kota Salatiga dengan menciptakan taman dengan bentuk arsitektur yang unik dan lengkap akan fasilitas. Kawasan Taman Tingkir yang mampu menjadi perhatian dan daya tarik masyarakat, mampu menimbulkan beragam aktivitas masyarakat dalam memanfaatkan taman tersebut. Dengan kondisi taman yang belum optimal namun mampu menjadi daya tarik perlu adanya perhatian pemerintah dalam hal menyelesaikan rencana Kawasan Taman Tingkir yang belum terlaksana, seperti belum optimalnya pembangunan kolam retensi, taman sehat, dan lahan parkir yang berada di sisi barat taman. Apabila rencana - rencana telah terealisasikan maka akan lebih dapat mendukung Kawasan Taman Tingkir sebagai ruang rekreasi di Kota Salatiga.

Masyarakat yang telah dimanjakan dengan keberadaan Taman Tingkir sebagai taman aktif dengan wajah baru di Kota Salatiga juga perlu mendapat perhatian oleh masyarakat atau pengguna ruang. Adapun bentuk perhatian yang perlu dilakukan oleh 
masyarakat atau pengguna ruang yakni perlunya keikut sertaan masyarakat dalam merawat taman seperti tidak mengotori taman, tidak merusak fasilitas yang tersedia. Selain itu juga perlu keikut sertaan masyarakat dalam mengikuti kegiatan pengolahan bahan bekas yang di programkan oleh Dinas Ciptaru Kota Salatiga guna mendukung program P2KH di Taman Tingkir.

\section{DAFTAR PUSTAKA}

Purnomohadi, N., \& Soedradjat, I. (2006). Ruang terbuka hijau sebagai unsur utama tata ruang kota. Direktorat Jenderal Penataan Ruang, Departemen Pekerjaan Umum..

Purwanto, Edi. (2007). Ruang Terbuka Hijau Di Perumahan Graha Estetika Semarang. Jurnal Enclosure, Volum 6 (1), 49-58.

Hakim, Rustam. (2004). Komponen Perancangan Arsitektur Lansekap. Jakarta : Bumi Aksara.

Carr, Stephen. (1992). Public Space, Combridge University Press. USA.

Lynch K., dan Carr S. (1960). Open Space: Freedom and Control, The Smithsonian Institution, London.

Badudu J.S dan Zain, Sutan Mohammad. (1996). Kamus Umum Bahasa Indonesia. Jakarta : Pustaka Sinar Harapan. 